\title{
Serum Levels of Prostate Specific Antigen Parameters among Male Patients with Lepromatous Leprosy in Edo State, Nigeria
}

\author{
Babatunde Ishola Gabriel Adejumo ${ }^{*}{ }^{(\mathbb{D}}$, David Osebhor ${ }^{1}$, Uchechukwu Dimkpa ${ }^{2}$, \\ Usman Itakure Abdulkadir ${ }^{3}$, Oladimeji Nasiru Abdulrahman4, Uzor Simon"5, \\ Kelechi Ncheta Nkwazema6 ${ }^{6}$, Noreen Ebelechukwu Agbapuonwu' ${ }^{7}$, Grace Umahi-Ottah ${ }^{8}$
}

${ }^{1}$ Medical Laboratory Science Department, University of Benin, Benin City, Nigeria

${ }^{2}$ Physiology Department, Nnewi Campus, Nnamdi Azikiwe University, Awka, Nigeria

${ }^{3}$ Department of Medical Laboratory Science, College of Health Sciences and Technology, Markafi, Kaduna State, Nigeria

${ }^{4}$ Department of Medical Laboratory Science, College of Health Technology, Offa, Kwara State

${ }^{5}$ Department of Applied Science, Faculty of Health and Applied Sciences, University of West of England, Bristol, UK

${ }^{6}$ Medical Laboratory Science Department, National Ear Care Centre, Kaduna, Kaduna State, Nigeria

${ }^{7}$ Department of Nursing, Nnamdi Azikwe University, Akwa, Nigeria

${ }^{8}$ Department of Physiology, Ebonyi State University, Abakaliki, Nigeria

Email: *babatunde.adejumo@uniben.edu

How to cite this paper: Adejumo, B.I.G., Osebhor, D., Dimkpa, U., Abdulkadir, U.I., Abdulrahman, O.N., Simon, U., Nkwazema, K.N., Agbapuonwu, N.E. and Umahi-Ottah, G. (2021) Serum Levels of Prostate Specific Antigen Parameters among Male Patients with Lepromatous Leprosy in Edo State, Nigeria. Health, 13, 920-933. https://doi.org/10.4236/health.2021.139071

Received: July 10, 2021

Accepted: September 7, 2021

Published: September 10, 2021

Copyright $\odot 2021$ by author(s) and Scientific Research Publishing Inc. This work is licensed under the Creative Commons Attribution International License (CC BY 4.0).

http://creativecommons.org/licenses/by/4.0/

\section{(c) (i) Open Access}

\begin{abstract}
Aim: This study is aimed at determining the total PSA (tPSA), free PSA (fPSA) concentrations and free to total PSA ratio (f/tPSA) and their utility in prostate cancer ( $\mathrm{PCa}$ ) risk stratification among male lepromatous leprosy patients in Edo state, Nigeria. Methods: Forty participants and thirty controls participated in this study. A structured questionnaire was administered to each participant to elicit details such as their personal data, age, sex, residence, medications, alcohol consumption, smoking habit, length of time of diagnosis, sexual activities, as well as the history of any other underlying diseases. Blood samples were collected from the participants. Total and free PSA concentrations in the samples were measured using ELISA method. Results: Significantly $(\mathrm{p}=0.042)$ higher serum fPSA among the leprosy patients $(0.22 \pm$ $0.12 \mathrm{ng} / \mathrm{ml})$ compared with the healthy controls $(0.17 \pm 0.09 \mathrm{ng} / \mathrm{ml})$. There were no significant $(\mathrm{p}=0.055)$ difference in the mean tPSA between the leprosy patients $(2.69 \pm 2.25 \mathrm{ng} / \mathrm{ml})$ compared with the control $(1.95 \pm 0.69$ $\mathrm{ng} / \mathrm{ml})$. Similarly, no significant $(\mathrm{p}=0.548)$ difference was observed in PSA ratio between the control $(0.08 \pm 0.04)$ and the leprosy patients $(0.09 \pm 0.03)$. Conclusion: Our study indicated no significant differences in tPSA and f/tPSA between the leprosy patients and their healthy control. Elevated tPSA as well as f/tPSA levels that fell within the high risk zones of PCa were more preva-
\end{abstract}


lent among patients aged $\geq 70$ years, not married, who rarely had sexual intercourse and those with longer disease duration.

\section{Keywords}

Serum, Prostate Cancer, Total PSA, Free PSA, Male, Leprosy

\section{Introduction}

Leprosy is a long-term infectious disease caused by the bacteria Mycobacterium leprae [1]. It is still endemic in Third World countries and remains a disease of public health importance in Nigeria with over 3500 people diagnosed with leprosy every year and about $25 \%$ of patients having some degree of disability [2]. Stigma and discrimination against persons and communities affected by leprosy in Nigeria are very high, due to myths and superstitions associated with fear of the disease [2]. Leprosy infection can lead to damage of the nerves, respiratory tract, skin, and other organs such as the testes, eyes, bones, and reticuloendothelial system [3]. The consequences of the effect of this disease may include among others: changes in secondary sex characteristics, such as gynaecomastia, sexual dysfunction and sterility [4] [5].

Prostate cancer ( $\mathrm{PCa}$ ) has become the most prevalent cancer among Nigerian men just as is being noted in other men of African descent in developing as well as in developed countries [6]. In 2014, the World Health Organization (WHO) reported 30,400 cancer-related deaths in Nigeria and $31.7 \%$ of these deaths were as a result of prostate cancer [7]. The introduction of screening techniques, which have enabled earlier diagnosis of patients, could be the reason for the increased incidence of $\mathrm{PCa}$ [8]. Measurement of serum prostate specific antigen (PSA) level is a recommended screening test for PCa, which helps in the determination of treatment options. Elevated prostate specific antigen (PSA $>4$ $\mathrm{ng} / \mathrm{ml}$ ) and or abnormal prostate architecture on digital rectal examination are indications for prostate biopsy [9]. In addition to screening, PSA is measured to evaluate the success of treatment and progression of disease when a known prostate carcinoma is present.

Prostate-specific antigen is a protein produced by normal, as well as malignant, cells of the prostate gland [10]. Serum PSA exists in the blood by itself (free form) or bound with other substances (complex form) [11] [12]. Total PSA is the sum of the free and the bound forms and is what is measured with the standard PSA test. Free-total-PSA ratio, a derivative of PSA assay is calculated from the measurement of free and total PSA and used in place of total PSA for prostate cancer screening [13] [14]. It is important to note that PSA is not specific to prostate cancer but to prostatic tissue, and therefore PSA elevations may indicate the presence of any kind of prostate disease and are regarded as a good marker for prostate volume. Common benign causes of PSA elevation include benign prostatic hyperplasia $(\mathrm{BPH})$, prostatitis, and urinary tract infection. 
Despite the increased awareness and practice of prostate cancer screening globally, the uptake has remained low especially in sub-Saharan African [15]. It is reported that the Nigerian male population is one of the most unscreened groups in the world with regards to prostate health [6]. Studies have shown that the awareness of prostate cancer among Nigerian men is poor [16] [17]. Likewise, routine prostate cancer screening is not a common practice in Nigeria [8], thus causing majority of the patients to present in the hospital when the disease is already advanced. Among these unscreened Nigerian males, those living with chronic infectious diseases such as leprosy are most affected due to the stigma and discrimination attached to such diseases. In this unscreened, high-risk group, assessment of their prostate health through screening techniques for $\mathrm{PCa}$ is a critical first step towards early detection and treatment and improving their quality of life. There has been no study investigating the level of total PSA, free PSA and free to total PSA ratio in patients with lepromatous leprosy in Nigeria, hence the justification for this work.

\section{Methods}

\subsection{Study Location}

This study was conducted at Daughters of Charity Rehabilitation Centre, in Ossiomo-Ogan in Edo State, Nigeria between September 2020 and March 2021. The Daughters of Charity Rehabilitation Centre is a specialized hospital that cares for lepromatous leprosy patients. The centre comprises of those who are disabled due to the effect of leprosy as well as those who are aged, and unable to care for themselves.

\subsection{Study Design}

The present study is a purposive, non-random sampling, cross sectional study comparing adult male lepromatous leprosy patients undergoing treatment with a healthy control group. A total of seventy males (40 infected males; 30 controls) within the ages of 40 - 90 years volunteered to participate in this study. The control group comprises of apparently healthy adults of the same age range, who have never had contact with leprosy patients or resided or worked near the leprosy settlement. The control group did not indicate any leprosy related symptoms or any disease conditions. Exclusion criteria included history of prostate cancer and the presence of other prostate abnormalities such as prostatitis and benign prostatic hyperplasia. Additionally, men of age less than 40 years; men with history of rectal manipulation or urological procedures (digital rectal examination, cystoscopy, urethral catheterization, rectal endoscopic intervention etc.); those with mechanical irritations (sexual intercourse, bicycling etc.) that can affect PSA levels 3 days prior to the study; those recently diagnosed of urinary tract infection; or had recent trauma arising from bladder or prostate examination involving biopsy were excluded from the study. The personal consent of individual participant was sought after explaining the purpose of the research. 


\subsection{Questionnaire/Ethical Approval}

A structured health and lifestyle screening questionnaire was administered to the participants prior to the test. The questionnaire consisted of questions designed to elicit details about the participants' personal data (age, marital status, occupation), residence, medications, alcohol consumption, smoking habit, sex life, history of PSA test, participation in PCa prevention program, knowledge and family history of prostate cancer, PCa screening and risk factors, as well as history of other underlying diseases. The Ethical Committee of the Ministry of Health, Edo State approved the study (file number: HA-737/48; Date of approval: $25^{\text {th }}$ September, 2020). The head of the center was also informed of the nature of the study and his permission was sought and obtained before the commencement of the study.

\subsection{Blood Collection and Analysis}

Five millilitres of blood was collected and dispensed into a plain container. The non anticoagulated blood was allowed to clot, spun at $1500 \mathrm{rpm}$ for 10 minutes and the supernatant serum was separated into a separate sterile tubes. The serum was stored at $-20^{\circ} \mathrm{C}$ for up to 2 weeks prior to analysis. Analysis for total PSA was done using commercially purchased ELISA kit from Calbiotech U.S.A. with catalog No PS235T, while free PSA was determined using ELISA kit from Calbiotech U.S.A. with catalog No PS233T respectively. The free-to-total PSA ratio of the patients was calculated.

\subsection{Data Analysis}

Descriptive data was expressed as mean \pm standard deviation for continuous data and percentages for categorical variables. Comparative analysis between variables was done using independent sample t-test. Correlation tests involving two variables were done using the Pearson's bivariate correlation test. Test of significance was set at $p<0.05$. All statistics were done using SPSS/IBM Software (version 20).

\section{Results}

Table 1 shows the demographics, lifestyle and clinical characteristics of the study population. A total of 70 subjects were recruited for this study including 30 uninfected controls, 40 patients living with leprosy. The mean age of the participants was 59.44 years (ranged from 40 to 91 years) with a SD of \pm 13.86 years. Majority of the control, 36.7\% were of age group 50 - 59 yrs; while most of the leprosy patients, $25.0 \%$ were of the age group $70-79$ years. Most $(80 \%)$ of the control subjects were married and $57.5 \%$ of the leprosy patients were single. Majority of the study population (control, $43.3 \%$ and leprosy patients, 70\%) were unemployed. Regarding their smoking and drinking habits, all the participants were non-smokers and non-alcoholics. A greater percentage of the control (36.7\%) has "recently" had sex with their spouses or partners, while $57.5 \%$ of the 
Table 1. Demographics, lifestyles and clinical characteristics of the study population.

\begin{tabular}{|c|c|c|c|}
\hline Characteristics & $\begin{array}{l}\text { Control }(n=30) \\
\text { Mean } \pm \text { SD } \\
\text { or } n(\%)\end{array}$ & $\begin{array}{c}\text { Leprosy Patients } \\
\quad(n=40) \\
\text { Mean } \pm \text { SD or } n(\%)\end{array}$ & $\begin{array}{c}\text { Total }(n=70) \\
\text { Mean } \pm \text { SD } \\
\text { or } n(\%)\end{array}$ \\
\hline Age (years) & $54.63 \pm 9.85$ & $63.05 \pm 15.38^{\star}$ & $59.44 \pm 13.86$ \\
\hline $40-49$ & $9(30.0)$ & $9(22.5)$ & $18(25.7)$ \\
\hline $50-59$ & $11(36.7)$ & $8(20.0)$ & $19(27.1)$ \\
\hline $60-69$ & $7(23.3)$ & $7(17.5)$ & $20(14.0)$ \\
\hline$\geq 70$ & $3(10.0)$ & $16(40.0)$ & $19(27.2)$ \\
\hline \multicolumn{4}{|l|}{ Marital Status } \\
\hline Single & $6(20.0)$ & $23(57.5)$ & $41(58.6)$ \\
\hline Married & $24(80.0)$ & $17(42.5)$ & $29(41.4)$ \\
\hline \multicolumn{4}{|l|}{ Occupation } \\
\hline Employed & $8(26.7)$ & $0(0)$ & $8(11.4)$ \\
\hline Unemployed & $9(30.0)$ & $12(30.0)$ & $21(30.0)$ \\
\hline Retired & $13(43.3)$ & $28(70.0)$ & $41(58.6)$ \\
\hline \multicolumn{4}{|l|}{ Smoking Habit } \\
\hline Non-smokers & $30(100)$ & $40(100)$ & $70(100)$ \\
\hline Smokers & $0(0)$ & $0(0)$ & $0(0)$ \\
\hline \multicolumn{4}{|l|}{ Alcoholic Habit } \\
\hline Non-drinkers & $30(100)$ & $40(100)$ & $70(100)$ \\
\hline Drinkers & $0(0)$ & $0(0)$ & $0(0)$ \\
\hline \multicolumn{4}{|c|}{ Last Sexual Intercourse } \\
\hline Recently & $11(36.7)$ & $10(25.0)$ & $21(30.0)$ \\
\hline Over 6 months & $10(33.3)$ & $7(17.5)$ & $17(24.3)$ \\
\hline Over a year & $9(30.0)$ & $23(57.5)$ & $32(45.8)$ \\
\hline \multicolumn{4}{|l|}{ Knowledge of PC } \\
\hline None & $28(93.3)$ & $40(100)$ & $68(97.1)$ \\
\hline Yes & $2(6.7)$ & $0(0)$ & $2(2.9)$ \\
\hline \multicolumn{4}{|c|}{ Knowledge of PC Risk Factors } \\
\hline None & $28(93.3)$ & $40(100)$ & $68(97.1)$ \\
\hline Yes & $2(6.7)$ & $0(0)$ & $2(2.9)$ \\
\hline \multicolumn{4}{|c|}{ Family History of PC } \\
\hline None & $30(100)$ & $40(100)$ & $70(100)$ \\
\hline Yes & $0(0)$ & $0(0)$ & $0(0)$ \\
\hline \multicolumn{4}{|c|}{ PC Screening History } \\
\hline None & $30(100)$ & $40(100)$ & $70(100)$ \\
\hline Yes & $0(0)$ & $0(0)$ & $0(0)$ \\
\hline
\end{tabular}




\section{Continued}

PSA Test History

$\begin{array}{lccc}\text { None } & 30(100) & 40(100) & 70(100) \\ \text { Yes } & 0(0) & 0(0) & 0(0) \\ \text { None } & & & \\ \text { Yes } & 30(100) & 40(100) & 70(100) \\ & 0(0) & 0(0) & 0(0)\end{array}$

Abbreviations: PC, Prostate Cancer; SD, Standard Deviation; PSA, Prostate Specific Antigen; ${ }^{\star}$ Significant difference in age between control and leprosy patients $(\mathrm{p}<0.05)$.

leprosy patients had their last sexual intercourse "over a year" ago. Majority of the participants (control, 93.3\%; leprosy patients, 100\%) had no knowledge of prostate cancer or its risk factors. All participants (control, 100\%; leprosy patients, $100 \%$ ) had no family history of prostate cancer, no history of prostate cancer screening, no history of PSA screening and have not participated in any prostate cancer prevention program.

Table 2 shows the clinical characteristics of the leprosy patients. The mean duration of the leprosy disease is $25.3 \pm 17.91$ years (range, $2-65$ years). A greater percentage (30\%) of the patients has suffered leprosy for 10 to 19 years. Majority of the patients had no family history of leprosy (100\%); had no previous leprosy diagnosis (77.5\%); were not on leprosy medication (80\%). Of the $20 \%$ that was under medication, $2(5 \%)$ were taking antibiotics, while $6(15 \%)$ were taking metronidazole.

The mean serum free prostate specific antigen in the control and leprosy patients is shown in Figure 1. Independent sample t-test indicated significantly ( $\mathrm{p}$ $=0.042)$ higher serum free PSA among the leprosy patients $(0.22 \pm 0.12 \mathrm{ng} / \mathrm{ml})$ compared with the healthy controls $(0.17 \pm 0.09 \mathrm{ng} / \mathrm{ml})$.

Figure 2 shows the mean serum total prostate specific antigen in the control and leprosy patients. A mean higher value was observed in the leprosy patients, however, independent sample t-test statistically indicated no significant $(\mathrm{p}=$ $0.055)$ difference in the mean total PSA between the leprosy patients $(2.69 \pm 2.25$ $\mathrm{ng} / \mathrm{ml})$ compared with the control $(1.95 \pm 0.69 \mathrm{ng} / \mathrm{ml})$.

The mean prostate specific antigen ratio in the control and leprosy patients is shown in Figure 3. Independent sample t-test indicated no significant ( $\mathrm{p}=$ $0.548)$ difference in PSA ratio between the control $(0.08 \pm 0.04)$ and the leprosy patients $(0.09 \pm 0.03)$.

The mean total PSA and free to total PSA levels according to the risk stratification for prostate cancer is expressed in Table 3.

Table 4 shows the distribution of the leprosy patients according to the prostate cancer risk levels based on PSA parameters. Data indicated that majority (70.6\%) of the patients who indicated low PCa risk based on total PSA level fell within the dangerous risk zone of the free to total PSA. Twenty three and half percent of the low risk (tPSA) patients also fell within the high risk zone of the 


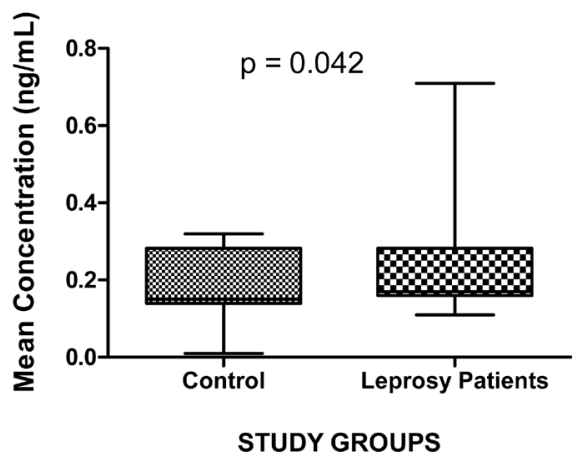

Figure 1. Mean serum free prostate specific antigen in the control and leprosy patients.

Table 2. Clinical characteristics of the leprosy patients $(n=40)$.

\begin{tabular}{|c|c|}
\hline Characteristics & Mean \pm SD or $n(\%)$ \\
\hline Duration of Disease (years) & $25.3 \pm 17.91$ \\
\hline$<10$ & $6(15.0)$ \\
\hline $10-19$ & $12(30.0)$ \\
\hline $20-29$ & $9(22.5)$ \\
\hline $30-39$ & $3(7.5)$ \\
\hline $40-49$ & $4(10.0)$ \\
\hline $50-59$ & $5(12.5)$ \\
\hline$\geq 60$ & $1(2.5)$ \\
\hline \multicolumn{2}{|l|}{ Family History of Leprosy } \\
\hline None & $40(100)$ \\
\hline Yes & $0(0)$ \\
\hline \multicolumn{2}{|l|}{ Leprosy Diagnosis } \\
\hline None & $31(77.5)$ \\
\hline Yes & $9(22.5)$ \\
\hline \multicolumn{2}{|l|}{ Leprosy Medication } \\
\hline None & $32(80.0)$ \\
\hline Yes & $8(20.0)$ \\
\hline \multicolumn{2}{|l|}{ Type of Medication } \\
\hline Antibiotics & $2(5.0)$ \\
\hline Metronidazole & $6(15.0)$ \\
\hline None & $32(80.0)$ \\
\hline
\end{tabular}

Table 3. Mean total PSA and free to total PSA according to the risk stratification for prostate cancer.

\begin{tabular}{cccc}
\hline $\begin{array}{c}\text { Risk Stratification for } \\
\text { PCa based on Total PSA }\end{array}$ & Number of Patients & Mean Total PSA Level & Mean PSA Ratio \\
\hline$<4 \mathrm{ng} / \mathrm{ml}$ & 34 & $1.96 \pm 0.27$ & $0.10 \pm 0.03$ \\
$4-10 \mathrm{ng} / \mathrm{ml}$ & 5 & $5.49 \pm 0.82$ & $0.05 \pm 0.03$ \\
$>10 \mathrm{ng} / \mathrm{ml}$ & 1 & 13.90 & 0.05 \\
Total & 40 & $2.69 \pm 2.25$ & $0.09 \pm 0.03$ \\
\hline
\end{tabular}




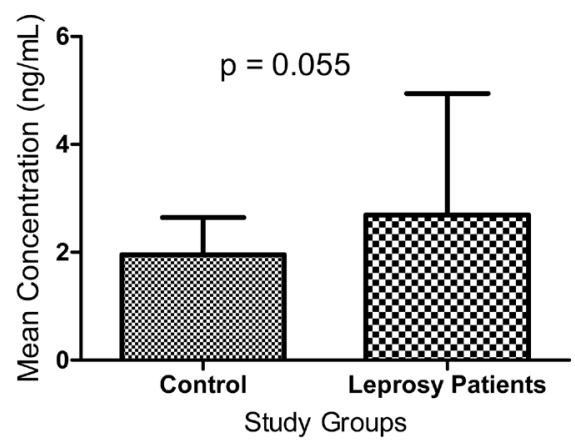

Figure 2. Mean serum total prostate specific antigen in the control and leprosy patients.

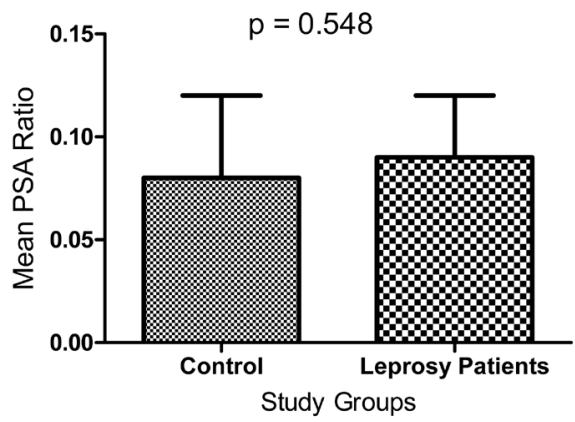

Figure 3. Mean prostate specific antigen ratio in the control and leprosy patients.

Table 4. Distribution of the leprosy patients according to the prostate cancer risk levels based on PSA parameters.

\begin{tabular}{|c|c|c|c|c|}
\hline \multirow{3}{*}{$\begin{array}{l}\text { Prostate Cancer Risk } \\
\text { Based on Free to } \\
\text { Total PSA Ratio }\end{array}$} & \multicolumn{3}{|c|}{ Prostate Cancer Risk Based on Total PSA Level } & \multirow[b]{2}{*}{ Total } \\
\hline & $\begin{array}{c}\text { Low } \\
\text { (15\% Risk) }\end{array}$ & $\begin{array}{c}\text { Intermediate } \\
\text { (25\% Risk) }\end{array}$ & $\begin{array}{c}\text { High } \\
(\geq 50 \% \text { Risk })\end{array}$ & \\
\hline & $\mathrm{N}=34$ & $\mathrm{~N}=5$ & $\mathrm{~N}=1$ & $\mathrm{~N}=40$ \\
\hline $\begin{array}{l}\text { Dangerous } \\
(\geq 56 \% \text { Risk) }\end{array}$ & $24(70.6)$ & $5(100)$ & $1(100)$ & $30(75.0)$ \\
\hline $\begin{array}{c}\text { High } \\
\text { (28\% Risk) }\end{array}$ & $8(23.5)$ & $0(0)$ & $0(0)$ & $8(20.0)$ \\
\hline $\begin{array}{l}\text { Moderate } \\
\text { (20\% Risk) }\end{array}$ & $2(5.9)$ & $0(0)$ & $0(0)$ & $2(5.0)$ \\
\hline $\begin{array}{c}\text { Low } \\
(16 \% \text { Risk) }\end{array}$ & - & - & - & - \\
\hline $\begin{array}{c}\text { Safe } \\
\text { (8\% Risk) }\end{array}$ & - & - & - & - \\
\hline
\end{tabular}

PCa stratification based on total PSA level: Low, $<4 \mathrm{ng} / \mathrm{ml}$; Borderline, $4-10 \mathrm{ng} / \mathrm{ml}$; High, $>10 \mathrm{ng} / \mathrm{ml}$. PCa stratification based on free/total PSA ratio: Safe, $\geq 0.25$; Low, 0.20 - 0.24; Moderate, 0.15 - 0.19; High, 0.10 0.14 ; Dangerous, $<0.10$.

f/tPSA. On the other hand, all patients who indicated intermediate risk $(n=5)$ as well as high risk $(\mathrm{n}=1)$ for PCa based on tPSA, fell within the dangerous risk zone of the f/tPSA. It is noteworthy that none of the patients fell within either low or safe risk zones of the f/tPSA. 
Table 5 shows the distribution of leprosy patients according to selected characteristics and prostate cancer risk levels based on total PSA. Data indicated that patients aged 70 years and above presented serum total PSA levels within the low risk (32.4\%), intermediate risk (80\%) and high risk $(100 \%, \mathrm{n}=1)$ stratifications. The married men had a greater incidence of total PSA of low risk (58.8\%) compared with the singles (41.2\%); higher incidence of tPSA within the intermediate risk range was found among the married men; the only high risk level tPSA concentration was observed in the singles category. Those who rarely had sexual intercourse with the opposite sex indicated greater incidence of serum tPSA levels within the low risk (73.5\%), intermediate risk (80\%) and high risk $(100 \%, \mathrm{n}=1)$ stratifications, compared with those that frequently had sexual intercourse. Patients who have suffered leprosy disease more than 10 years also indicated greater incidence of serum tPSA levels within the low risk (73.5\%), intermediate risk $(80 \%)$ and high risk $(100 \%, \mathrm{n}=1)$ stratifications, compared with those whose disease duration were less than 10 years.

Table 6 distributed the patients' population according to the stratification for prostate cancer risk using the free to total PSA ratio. Values that fell within the dangerous risk zone were more prevalent in patients aged $\geq 70$ years $(46.7 \%)$;

Table 5. Distribution of leprosy patients according to selected characteristics and prostate cancer risk levels based on total PSA.

\begin{tabular}{|c|c|c|c|c|}
\hline \multirow{3}{*}{$\begin{array}{c}\text { Patients' } \\
\text { Characteristics }\end{array}$} & $\begin{array}{c}\text { Low } \\
\text { (15\% Risk); }\end{array}$ & $\begin{array}{l}\text { Intermediate } \\
\text { (25\% Risk); }\end{array}$ & $\begin{array}{c}\text { High } \\
(\geq 50 \% \text { Risk); }\end{array}$ & Total \\
\hline & $\mathrm{n}=34$ & $\mathrm{n}=5$ & $\mathbf{n}=1$ & $\mathrm{n}=40$ \\
\hline & $\mathrm{N}(\%)$ & $\mathrm{N}(\%)$ & $\mathrm{N}(\%)$ & N (\%) \\
\hline \multicolumn{5}{|l|}{ Age (yrs) } \\
\hline $40-49$ & $8(23.5)$ & $1(20.0)$ & $0(0)$ & $9(22.5)$ \\
\hline $50-59$ & $8(23.5)$ & $0(0)$ & $0(0)$ & $8(20.0)$ \\
\hline $60-69$ & $7(20.6)$ & $0(0)$ & $0(0)$ & $7(17.5)$ \\
\hline$\geq 70$ & $11(32.4)$ & $4(80.0)$ & $1(100)$ & $16(40.0)$ \\
\hline \multicolumn{5}{|l|}{ Marital Status } \\
\hline Single & $20(58.8)$ & $2(40.0)$ & $1(100)$ & $23(57.5)$ \\
\hline Married & $14(41.2)$ & $3(60.0)$ & $0(0)$ & $17(42.5)$ \\
\hline \multicolumn{5}{|l|}{ Frequency of Sexual } \\
\hline \multicolumn{5}{|l|}{ Intercourse } \\
\hline Regular & $9(26.5)$ & $1(20.0)$ & $0(0)$ & $10(25.0)$ \\
\hline Rarely & $25(73.5)$ & $4(80.0)$ & $1(100)$ & $30(75.0)$ \\
\hline \multicolumn{5}{|c|}{ Duration Disease (yrs) } \\
\hline $1-10$ & $9(26.5)$ & $1(20.0)$ & $0(0)$ & $10(25.0)$ \\
\hline$>10$ & $25(73.5)$ & $4(80.0)$ & $1(100)$ & $30(75.0)$ \\
\hline
\end{tabular}

PCa stratification based on total PSA level: Low, $<4$ ng/ml; Borderline, 4 - 10 ng/ml; High, $>10$ ng/ml. 
Table 6. Distribution of leprosy patients according to selected characteristics and prostate cancer risk levels based on free to total PSA ratio.

\begin{tabular}{|c|c|c|c|c|}
\hline \multirow{3}{*}{ Patients' Characteristics } & $\begin{array}{l}\text { Dangerous } \\
\text { ( } \geq 56 \% \text { Risk); }\end{array}$ & $\begin{array}{c}\text { High } \\
\text { (28\% Risk); }\end{array}$ & $\begin{array}{c}\text { Moderate } \\
\text { ( } \geq 20 \% \text { Risk); }\end{array}$ & Total \\
\hline & $\mathrm{n}=30$ & $\mathrm{n}=8$ & $\mathrm{n}=2$ & $\mathrm{n}=40$ \\
\hline & $\mathrm{N}(\%)$ & $\mathrm{N}(\%)$ & $\mathrm{N}(\%)$ & N (\%) \\
\hline \multicolumn{5}{|l|}{ Age (yrs) } \\
\hline $40-49$ & $6(20.0)$ & $2(25.0)$ & $1(50.0)$ & $9(22.5)$ \\
\hline $50-59$ & $6(20.0)$ & $2(25.0)$ & $0(0)$ & $8(20.0)$ \\
\hline $60-69$ & $4(13.3)$ & $2(25.0)$ & $1(50.0)$ & $7(17.5)$ \\
\hline$\geq 70$ & $14(46.7)$ & $2(25.0)$ & $0(0)$ & $16(40.0)$ \\
\hline \multicolumn{5}{|l|}{ Marital Status } \\
\hline Single & $19(63.3)$ & $3(37.5)$ & $1(50.0)$ & $23(57.5)$ \\
\hline Married & $11(36.7)$ & $5(62.5)$ & $1(50.0)$ & $17(42.5)$ \\
\hline \multicolumn{5}{|l|}{ Frequency of Sexual } \\
\hline \multicolumn{5}{|l|}{ Intercourse } \\
\hline Regular & $7(23.3)$ & $3(37.5)$ & $1(50.0)$ & $23(57.5)$ \\
\hline Rarely & $23(76.7)$ & $5(62.5)$ & $1(50.0)$ & $17(42.5)$ \\
\hline \multicolumn{5}{|l|}{ Duration Disease (yrs) } \\
\hline $1-10$ & $8(26.7)$ & $2(25.0)$ & $0(0)$ & $10(25.0)$ \\
\hline$>10$ & $22(73.3)$ & $6(75.0)$ & $2(100)$ & $30(75.0)$ \\
\hline
\end{tabular}

PCa stratification based on free/total PSA ratio: Safe, $\geq 0.25$; Low, 0.20 - 0.24; Moderate, 0.15 - 0.19; High, 0.10 - 0.14; Dangerous, $<0.10$.

those not married (63.3\%); patients who rarely had sexual intercourse (76.7\%); and those with longer disease duration (73.3\%). Percentage of patients that fell within the high risk zone did not differ among the age groups; greater in the married compared with single men (62.5\% vs. $37.5 \%)$; greater in patients who rarely engaged in sexual intercourse compared with those who frequently had sex (62.5\% vs. $37.5 \%)$; and greater in those with longer duration of disease compared with those of shorter disease duration ( $75 \%$ vs. $25 \%)$.

\section{Discussion}

The present study indicated no significant differences in mean total PSA levels between the leprosy patients and their healthy control. The mean total PSA (2.69 $\pm 2.25 \mathrm{ng} / \mathrm{ml}$ ) also fell within the normal range of serum total PSA $(0-4 \mathrm{ng} / \mathrm{ml})$. In a previous study the mean tPSA value of the patients with leprosy was found to be significantly lower compared with the control [18]. Our data further indicated that majority $(84.9 \%, \mathrm{n}=34)$ of the patients' total PSA levels fell within the low risk PCa zone $(0-4.0 \mathrm{ng} / \mathrm{ml})$. Of this number, 33 (82.5\%) fell within the safe zone $(0-2.5 \mathrm{ng} / \mathrm{ml})$. The remaining $15 \%(\mathrm{n}=6)$ of the patients were distributed across the intermediate risk, (12.5\%) and high risk (2.5\%) PCa zones. In the light 
of the present study, it appears that the risk of leprosy may be very low among the leprosy patients. However, caution must be applied while interpreting total PSA results since the test doesn't always provide an accurate result. Recent studies have shown that some men with PSA levels below $4.0 \mathrm{ng} / \mathrm{mL}$ have prostate cancer and that many men with higher levels do not have prostate cancer [19]. In addition, various factors can cause a man's PSA level to fluctuate. For example, a man's PSA level often rises if he has BPH, prostatitis or a urinary tract infection. PSA levels also tend to increase in all men as they age.

In order to increase the sensitivity and specificity of total PSA, different indexes have been developed. The free to total PSA is one of such parameters used to improve the sensitivity of cancer detection when total PSA is in the normal range $(<4 \mathrm{ng} / \mathrm{mL})$ and to increase the specificity of cancer detection when total PSA in the "gray zone" (4.1 to $10 \mathrm{ng} / \mathrm{mL}$ ) [20]. In this latter group, the lower the value of free to total PSA, the greater is the likelihood that an elevated PSA represents cancer and not BPH [11]. The present study indicated no significant difference between the control and the leprosy patients. However, the mean free-to-total PSA ratio was found to be $0.09 \pm 0.03$ in patients with leprosy, which is well below the general cut-off level of 0.18 accepted for the free-to-total PSA ratio. Similarly, our data indicated values lower than PSA ratio cut-off of $>0.23$ for tPSA values of 4 to $10 \mu \mathrm{g} / \mathrm{L}$ and the cut-off level of $>0.15$ for tPSA values below $4 \mu \mathrm{g} / \mathrm{L}$ (Table 3 ). Furthermore, seventy five percentage $(\mathrm{n}=30)$ of the patient population had free to total PSA level that fell within the "danger" zone; $20 \%(\mathrm{n}=8)$ fell within the high risk zone; and $5 \%(\mathrm{n}=2)$ fell within the moderate risk zone. In contrast to our finding, a previous study has demonstrated a significantly higher mean free to total PSA ratio in the leprosy group compared with the control [18]. A lower free to total PSA ratio strongly suggests risk of prostate carcinoma. Furthermore, our results re-affirm the increased sensitivity of the free to total PSA ratio and its significance in reducing the number of false-positive results often associated with total PSA.

Total PSA levels that fell within the intermediate and high risk zones were mostly presented by patients aged $\geq 70$ years, not married, who rarely had sexual intercourse and those with longer disease duration. Similarly, PSA ratio that fell within the dangerous risk zone were more prevalent in patients aged $\geq 70$ years (46.7\%); those not married (63.3\%); patients who rarely had sexual intercourse (76.7\%); and those with longer disease duration (73.3\%). Ageing is the most common risk factor of prostate cancer [21]. Previous studies have also shown positive relationships between ageing and PSA level [22] [23]. Prostate cancer has been linked to reduced sexual desire as well as reduced frequency of sexual intercourse [24]. Previous studies [25] [26] [27] have also reported a significant positive correlation between levels of sexual activity and serum testosterone levels in older men aged above 40 years. Furthermore it has been speculated that changes in androgenic hormonal levels of patients with lepromatous leprosy may cause a change in prostate-specific antigen (PSA) parameters [18]. Testicular atrophy emerges most frequently in lepromatous leprosy, thus reducing the 
patients' serum total testosterone levels [4] [28]. Studies have also shown that low serum testosterone levels was associated with undifferentiated tumors and advanced tumor stage [29] [30] [31]. However, it is not clear if these changes in androgen levels are related to duration of the leprosy disease to cause the risk of prostate carcinoma.

\section{Conclusion}

In this study, there were no significant differences in total PSA and free to total PSA between the leprosy patients and their healthy control. Elevated total PSA as well as free to total PSA levels that fell within the high risk zones of PCa were more prevalent among patients aged $\geq 70$ years, not married, who rarely had sexual intercourse and those with longer disease duration.

\section{Conflicts of Interest}

The authors declare no conflicts of interest regarding the publication of this paper.

\section{References}

[1] Bassukas, I.D., Gaitanis, G. and Hundeiker, M. (2012) Leprosy and the Natural Selection for Psoriasis. Medical Hypotheses, 78, 183-190. https://doi.org/10.1016/j.mehy.2011.10.022

[2] Nigeria Centre for Disease Control (2017) Leprosy. NCDC. https://ncdc.gov.ng/diseases/factsheet/33

[3] Forno, C., Hausermann, P., Hatz, C., et al. (2010) The Difficulty in Diagnosis and Treatment of Leprosy. Journal of Travel Medicine, 17, 281-283. https://doi.org/10.1111/j.1708-8305.2010.00419.x

[4] Saporta, L. and Yuksel, A. (1994) Androgenic Status in Patients with Lepromatous Leprosy. British Journal of Urology, 74, 221-224. https://doi.org/10.1111/j.1464-410X.1994.tb16590.x

[5] Abd-Elkawi, F.A., Bahgat, S.A., Kamel, A.M., Farag, A.S. and Ashor, O.M. (2014) Testicular Function in Male Patients with Lepromatous Leprosy. Egyptian Journal of Dermatology and Venerology, 34, 41-45. https://doi.org/10.4103/1110-6530.137307

[6] Akinremi, T.O., Adeniyi, A., Olutunde, A., Oduniyi, A. and Ogo, C.N. (2014) Need for and Relevance of Prostate Cancer Screening in Nigeria. Ecancer, 8, 457.

[7] Ugochukwu, U.V., Odukoya, O.O., Ajogwu, A. and Ojewola, R.W. (2019) Prostate Cancer Screening: What Do Men Know, Think and Do about Their Risk? Exploring the Opinions of Men in an Urban Area in Lagos State, Nigeria: A Mixed Methods Survey. Pan African Medical Journal, 34, 168. https://doi.org/10.11604/pamj.2019.34.168.20921

[8] Ogunbiyi, J.O. and Shittu, O.B. (1999) Increased Incidence of Prostate Cancer in Nigerians. Journal of the National Medical Association, 91, 159-164.

[9] Streicher, J., Meyerson, B.L., Karivedu, V. and Sidana, A. (2019) A Review of Optimal Prostate Biopsy Indications and Techniques. Therapeutic Advances in Urology, 11, 1-8. https://doi.org/10.1177/1756287219870074

[10] U.S. Department of Health and Human Services. Prostate-Specific Antigen (PSA) 
Test. National Cancer Institute Fact Sheet. https://www.cancer.gov/types/prostate/psa-fact-sheet

[11] Catalona, W., Partin, A., Slawin, K., et al. (1998) Use of the Percentage of Free Prostate-Specific Antigen to Enhance Differentiation of Prostate Cancer from Benign Prostatic Disease: A Prospective Multicenter Clinical Trial. JAMA, 279, 1542-1547. https://doi.org/10.1001/jama.279.19.1542

[12] Hoffman, R.M., Clannon, D.L., Littenberg, B., Frank, J.J. and Pierce, J.C. (2000) Using the Free to Total Prostate Specific Antigen Ratio to Detect Prostate Cancer in Men with Non-Specific Elevations of Prostate Specific Antigen Level. Journal of General Internal Medicine, 15, 739-748. https://doi.org/10.1046/j.1525-1497.2000.90907.x

[13] McCormack, R.T., Rittenhouse, H.G., Finlay, J.A., et al. (1995) Molecular Forms of Prostate-Specific Antigen and the Human Kallikrein Gene Family: A New Era. Urology, 45, 729-744. https://doi.org/10.1016/S0090-4295(99)80076-4

[14] Vessella, R.L., Lange, P.H., et al. (1997) Issues in the Assessment of Prostate-Specific Antigen Immunoassays. An Update. Urologic Clinics of North America, 24, 261-268. https://doi.org/10.1016/S0094-0143(05)70371-2

[15] Ikuerowo, S.O., Omisanjo, O.A., Bioku, M.J., Ajala, M.O., Mordi, V.P.N. and Esho, J.O. (2013) Prevalence and Characteristics of Prostate Cancer among Participants of a Community-Based Screening in Nigeria Using Serum Prostate Specific Antigen and Digital Rectal Examination. The Pan African Medical Journal, 15, 129. https://doi.org/10.11604/pamj.2013.15.129.2489

[16] Ajape, A.A., Babata, A. and Abiola, O.O. (2010) Knowledge of Prostate Cancer Screening among Native African Urban Population in Nigeria. Nigerian Quarterly Journal of Hospital Medicine, 20, 94-96. https://doi.org/10.4314/nqjhm.v20i2.58044

[17] Ukoli, F., Osime, U., Akereyeni, F., Okunzuwa, O., Kittles, R. and Adams-Campbell, L. (2003) Prevalence of Elevated Serum Prostate-Specific Antigen in Rural Nigeria. International Journal of Urology, 10, 315-322. https://doi.org/10.1046/j.1442-2042.2003.00633.x

[18] Erdogan, A., Cemal, T., Mehmet, O.Y., Cavit, C. and Ilker, E. (2014) Prostatic and Testicular Parameters in Lepromatous Patients. Leprosy Review, 85, 48-53. https://doi.org/10.47276/lr.85.1.48

[19] Thompson, I.M., Pauler, D.K., Goodman, P.J., et al. (2004) Prevalence of Prostate Cancer among Men with a Prostate-Specific Antigen Level $<$ or $=4.0$ ng per Milliliter. New England Journal of Medicine, 350, 2239-2246. https://doi.org/10.1056/NEJMoa031918

[20] Adhyam, M. and Gupta, A.K. (2012) A Review on the Clinical Utility of PSA in Cancer Prostate. Indian Journal of Surgical Oncology, 3, 120-129. https://doi.org/10.1007/s13193-012-0142-6

[21] Center for Disease Control and Prevention. Who Is at Risk for Prostate Cancer? https://www.cdc.gov/cancer/prostate/basic_info/risk_factors.htm

[22] Baruah, S.K., Nath, S.J., Puthenveetil, R.T., Baruah, S.J., Deka, P.M. and Bawri, B. (2012) Correlation of Age, Prostate Volume, Serum Prostate-Specific Antigen, and Serum Testosterone in Indian, Benign Prostatic Hyperplasia Patients. UroToday International Journal, 5, 1-6. https://doi.org/10.3834/uij.1944-5784.2012.10.02

[23] Lee, S.E., Chung, J.S., Han, B.K., Moon, K.H., Hwang, S.I. and Lee, H.J. (2008) Relationship of Prostate-Specific Antigen and Prostate Volume in Korean Men with Biopsy-Proven Benign Prostatic Hyperplasia. Urology, 71, 395-398. https://doi.org/10.1016/j.urology.2007.10.019 
[24] Hyun, J.S. (2012) Prostate Cancer and Sexual Function. The World Journal of Men's Health, 30, 99-107. https://doi.org/10.5534/wjmh.2012.30.2.99

[25] Tsitouras, P.D., Martin, C.E. and Harman, S.M. (1982) Relationship of Serum Testosterone to Sexual Activity in Healthy Elderly Men. The Journals of Gerontology, 37, 288-293. https://doi.org/10.1093/geronj/37.3.288

[26] Gades, N.M., Jacobson, D.J., McGree, M.E., et al. (2008) The Associations between Serum Sex Hormones, Erectile Function, and Sex Drive: The Olmsted County Study of Urinary Symptoms and Health Status among Men. The Journal of Sexual Medicine, 5, 2209-2220. https://doi.org/10.1111/j.1743-6109.2008.00924.x

[27] O’Connor, D.B., Lee, D.M., Corona, G., et al. (2011) The Relationships between Sex Hormones and Sexual Function in Middle-Aged and Older European Men. The Journal of Clinical Endocrinology \& Metabolism, 96, E1577-E1587.

[28] Kiriyama, I., Ohgaki, K., Ohba, S., et al. (2003) Prostate Cancer in Patients with Hansen's Disease. International Journal of Urology, 10, 177-179. https://doi.org/10.1046/j.1442-2042.2003.00584.x

[29] Massengill, J.C., Sun, L., Moul, J.W., Wu, H., McLeod, D.G., Amling, C., et al. (2003) Pretreatment Total Testosterone Level Predicts Pathological Stage in Patients with Localized Prostate Cancer Treated with Radical Prostatectomy. Journal of Urology, 169, 1670-1676. https://doi.org/10.1097/01.ju.0000062674.43964.d0

[30] Morgentaler, A., Bruning, C.O. and DeWolf, W.C. (1996) Occult Prostate Cancer in Men with Low Serum Testosterone Levels. JAMA, 276, 1904-1906.

https://doi.org/10.1001/jama.276.23.1904

[31] Yamamoto, S., Yonese, J., Kawakami, S., Ohkubo, Y., Tatokoro, M., et al. (2007) Preoperative Serum Testosterone Levels as an Independent Predictor of Treatment Failure Following Radical Prostatectomy. European Urology, 52, 696-701. https://doi.org/10.1016/j.eururo.2007.03.052 